Instructions for authors, subscriptions and further details:

\title{
Long-term Societal Impacts of Conditional Cash Transfers: Bolsa Família a Decade in
}

Brian Warby ${ }^{1}$

1) University of Northern lowa, United States

Date of publication: March $30^{\text {th }}, 2018$

Edition period: March 2018 - July 2018

To cite this article: Warby, B. (2018). Long-term Societal Impacts of Conditional Cash Transfers: Bolsa Família a Decade in. International and Multidisciplinary Journal of Social Sciences, 7(1), 79-103. doi:

10.17583/rimcis.2018.3200

To link this article: http://doi.org/10.17583/rimcis.2018.3200

\section{PLEASE SCROLL DOWN FOR ARTICLE}

The terms and conditions of use are related to the Open Journal System and to Creative Commons Attribution License (CC-BY). 


\section{Long-term Societal Impacts of Conditional Cash Transfers: Bolsa Família a Decade in}

Brian Warby

University of Northern Iowa

\section{Abstract}

Conditional Cash Transfers (CCTs) are innovative poverty intervention programs that have been adapted and adopted in dozens of countries around the world. The effectiveness of the programs in the short-term have been established by a number of studies, but they have only recently been around long enough to begin to observe whether they indeed disrupt the inter-generational poverty cycle as claimed. The expected long-term effects are central to the appeal of CCT programs. This empirical study examines the data to determine whether there is evidence that the long-term effects are as apparent as the short-term effects in one of the original adopters, Brazil. The analysis examines municipal level government data using OLS regression and finds evidence that CCTs raised $8^{\text {th }}$ grade graduation rates and lowered unemployment and birthrates. The conclusion is that, at least in Brazil, CCTs seem to be making headway in changing conditions that often lead to intergenerational poverty cycles.

Keywords: conditional cash transfers (CCTs), Brazil, poverty alleviation, development, poverty cycle 


\section{Impactos Sociales a Largo Plazo de las Transferencias Monetarias Condicionadas: Una Década de la Bolsa Família}

Brian Warby

University of Northern Iowa

\section{Resumen}

Las Transferencias Monetarias Condicionadas (CCT) son programas innovadores de intervención contra la pobreza que se han adaptado y adoptado en decenas de países de todo el mundo. Varios estudios han establecido la eficacia de los programas a corto plazo, pero solo recientemente han existido tiempo suficiente como para comenzar a observar si realmente perturban el ciclo de pobreza intergeneracional tal como se afirma. Los efectos esperados a largo plazo son centrales para el atracción de los programas de CCT. Este estudio empírico examina los datos para determinar si hay evidencia de que los efectos a largo plazo son tan evidentes como los efectos a corto plazo en uno de los adoptantes originales, Brasil. El análisis examina los datos del gobierno a nivel municipal, utilizando la regresión MCO y encuentra evidencia de que los CCT elevaron las tasas de graduación del octavo grado y redujeron el desempleo y la tasa de fecundidad. La conclusión es que, al menos en Brasil, las CCT parecen estar avanzando las condiciones que a menudo conducen a ciclos de pobreza intergeneracionales.

Palabras clave: transferencias monetarias condicionadas, Brasil, reducción de la pobreza, desarrollo, ciclo de la pobreza 
I

$\mathrm{n}$ the late 90s, both Mexico and Brazil independently began building domestic poverty alleviation programs that would soon from policymakers to non-profits, to academics. There were two key ideas behind these programs. The first was to simply give poor families cash transfers rather than in-kind transfers. This allows each recipient household to use the cash according to their needs, at face value, rather than being offered something they do not need or having to exchange commodities for a fraction of their true value to acquire more useful goods (Fiszbein \& Schady, 2009).

The second key element of these plans was to use the cash transfers to induce long-term investment in human capital that might help break intergenerational poverty cycles. Poor families would have to enroll their children in school and ensure their attendance. They would also have to ensure that children were meeting minimum health and growth trajectories. Families that failed to meet these conditions would not receive the cash transfers. Thus, the children of poor families would have a better chance of breaking out of poverty as the program gave them the tools they needed to secure better employment and avoid many of the pitfalls that often entrap the poor.

Brazil's Bolsa Família program received a large boost in 2003 when President Lula consolidated several smaller programs and increased the scope and funding for the newly unified conditional cash transfer (CCT) program. It took time to scale up, but today Bolsa Família reaches more than 11 million households, or over 40 million people. Benefits can range up to $\mathrm{R} \$ 200$ per month, depending on the number of qualifying children in the household and household income. The families who are eligible to enroll in the program are the very poor, with average household incomes of about R\$243 per month (Rawlings \& Rubio, 2005). So Bolsa Família represents a huge proportion of monthly income for some families. However, the program is surprisingly inexpensive. Bolsa Família reportedly accounts for only about $0.3 \%$ of GDP (Secretaria Nacional de Renda de Cidadania, 2010; Schultz, 1997).

Nevertheless, the short-term impact of Bolsa Família has been wellestablished. Bolsa Família and other CCTs significantly reduce under-5 
mortality from malnutrition (McCrary \& Royer, 2011), increase the use of preventative health services (Sen, 1999), improve overall mortality figures (World Bank, 2012) and increase school enrollment (Behrman, 1996; Rasella, Aquino, Santos, Paes-Sousa \& Barreto, 2013). The successes of CCT programs in Brazil and elsewhere have sparked the interests and hopes of policymakers in many more countries. The World Bank reports that at least thirty countries now have some form of CCT program (Fiszbein \& Schady, 2009).

While these short-term results look promising, and indeed have already had a significant impact on immediate poverty concerns, the programs are new enough that it has been difficult to observe whether the short-term results also produce long-term changes. Myriad studies have reported on the immediate poverty alleviation outcomes, which represent the first objective of the program. This paper is a first look at some of the long-term effects we might expect to see at the societal level. It uses data on how thoroughly Bolsa Família was implemented at the municipal level to get some leverage on long-term impacts and making progress towards disrupting intergenerational poverty cycles. It does this by looking for tell-tale indicators such as changes in fertility rates which often indicates improved educational outcomes and empowerment for girls and women; educational achievement, which goes beyond simple enrollment to examine changes in earning potential; and unemployment, a measure of changing labor markets and opportunities available to low-income households.

\section{Objectives of CCTs}

The two-pronged approach of Bolsa Família is appealing to many policymakers. With the large number of poor Brazilians, the government must concern itself with their welfare for both political and humanitarian reasons. Poverty is rampant, and hunger and malnutrition are not uncommon for many Brazilians. Second, it is hoped that the program will help break the inter-generational poverty cycle (Rawlings \& Rubio, 2005). Not only are millions of Brazilians mired in the mud pit of poverty, their children are unlikely to be any better off. The opportunities that poverty takes away from children of poor families will cost them education, income and fulfillment 
for the rest of their lives. Combining the two facets of poverty alleviation into a single program is one of the things that makes CCTs appealing to so many people and governments.

Bolsa Família helps address immediate needs by providing qualifying families with income supplements. The appeal of cash transfers, as opposed to in-kind transfers for example, is the gain in efficiency. Tax payers and politicians often like the control that in-kind transfers give them, since they can control how much, and what kinds of commodities program recipients are receiving. This, presumably, gives them confidence that recipients are not squandering tax dollars on frivolous pursuits or purchasing luxuries that tax payers themselves do not have. The problem, though, is that in-kind transfers are less efficient than cash transfers. They require greater government oversight to specify the types and quantities of commodities that the recipients receive, and to try and prevent recipients from exchanging the commodities the program gives them for non-essential items.

Cash transfer programs eliminate the paternalism inherent to in-kind transfers. They require less government oversight because program facilitators need only verify that conditions are being met and that cash is being deposited into beneficiaries' bank accounts. Recipients are free to select the types and quantities of commodities or services that will benefit them most. Some recipients, for example, may have the ability to grow a large garden, but an in-kind transfer provides them with produce and takes away their incentive to optimize their garden plot. The cash transfer allows them to use part of the transfer to buy seed and fertilizer to grow the produce they need, and still leave some left over. They can choose to shop carefully, buying the commodities they need at the best possible price, and cutting out commodities that they do not need in order to maximize their benefit. This serves to make the program more impactful.

Moreover, we may see impacts from education-based conditions in other areas too. For example, a strong body of literature has shown robust correlations between female education and fertility rates, with good reason to believe that greater education leads to lower fecundity (McCrary \& Royer, 2011; Schultz, 1997). Female education gives women better tools for family planning, addressing health and, perhaps, asserting a stronger role in their relationships. Sen (1999) demonstrated that increasing female education 
pays big dividends in child mortality rates. Increasing female education also opens opportunities for women to enter the workforce, which also reduces fecundity rates (World Bank, 2012). We could not observe whether this was occurring as a result of the Bolsa Família program until the first generation of students who were incentivized to remain in school eventually began having children of their own. At that point, the additional time spent in school may lead those women to have fewer children.

Bolsa Família's conditions also compel families to invest in health. Children and pregnant or lactating mothers are required to attend regular medical checkups, receive standard vaccinations and be on target with healthy growth trajectories, a common indicator of malnutrition. Brazil's Family Health Program means that there is no fees associated with medical visits, but before the program, many people, especially the poor, did not always receive the medical care they needed for long-term health. For some, the inconvenience of distant clinics deterred them from receiving regular medical attention. For others, it may simply have been a matter of priorities. Consequently, although it is improving, child mortality is still much higher in Brazil than in high-income countries. Under-5 mortality in Brazil was at 17.5 deaths per 1000 live births in 2009 (Rasella et al., 2013). This is slightly higher than Argentina's rate of 15, but lower than Colombia's rate of 19 or Paraguay's at 24. A number of those deaths occurred from easily treatable, poverty related causes, such as diarrheal diseases, malnutrition and lower respiratory infections.

The human costs of child mortality are devastating, but difficult to quantify. It is easier to study the effects of childhood health. Research has uncovered consistent evidence that anemia and parasitic infections affect cognitive achievement (Behrman, 1996). Another study found that a dollar invested in childhood nutrition in a developing country would likely return at least three dollars' worth of gains in academic achievement (Glewwe, Jacoby \& King, 2001). Children who receive adequate nutrition are taller, enter school earlier and achieve academic advancements faster (Alderman, Hoddinott \& Kinsey, 2006). Bolsa Família's design tries to address the effect that health has on educational achievement and child mortality through its mandatory medical visits. The evidence indicates that these interventions are successful, increasing the use of preventive services and 
reducing under-5 mortality (Lagarde, Haines \& Palmer, 2007; Rasella et al., 2013).

The question that remains, however, is whether these short-term changes in child health translate into long-term effects. If children are generally healthier, this should contribute to greater academic success, as mentioned above, but should manifest in other facets of society as well. For example, we might observe a decrease in infant mortality in the short term since healthier mothers should have healthier pregnancies and healthier babies (Alderman et al., 2006). Also, as those young girls grow up with better nutrition and begin to bear children of their own, their improved health and education should lead to additional reductions in infant and child mortality over the long term (Rasella et al., 2013).

\section{Theory}

As addressed in the introduction, Bolsa Família has had significant, measurable, short-term impacts on both health outcomes and school enrollment. This paper will be tracking those impacts as the program approaches its twentieth year. In analyzing long-term impacts, one might also expect to see changes in employment patterns as some of the first child beneficiaries of the program are now in the 18-24 year old demographic range. All three of these components; health, education, and employment are measurable independently but in reality they are inherently intertwined.

One of the first initiatives of the Bolsa program was immediate poverty alleviation in the form of cash transfers to parents in conjunction with regular medical checkups in order to ensure that child beneficiaries were receiving adequate nutrition. It has long been known that a nutritious diet is critical for optimal brain development and function, and that the timing of nutrient supplementation or deprivation also matters (Bryan et al., 2004). Since the program requires that children display healthy growth trajectories, parents have large incentives to ensure that children receive adequate nutrition. In addition to relieving a portion of human suffering, one could expect to see the impacts of better nutrition manifest other ways. For example, it may contribute to academic achievement, since those children will be better able to learn in school. 
The school attendance requirements will also likely contribute to better academic achievement. The structure of Bolsa Família assumes that the poor are capable of- and motivated to address their short-term needs. The pinch of poverty has taught them to manage their resources carefully (Collins, Morduch, Rutherford, \& Ruthven, 2009). Indeed, evidence consistently shows that cash transfer programs increase consumption in most cases, reducing both poverty headcount and the poverty gap (Fiszbein \& Schady, 2009). However, the structure of CCTs also assumes that poor families are not always good at investing in the future. It may be a result of ignorance of the return an investment may yield in the future, or simply because the ache of hunger compels them to focus on present consumption to the exclusion of future considerations. The requirements, or conditions, that potential beneficiaries must meet in order to receive assistance forces them to make human capital investments that are expected to give children a better chance at climbing out of the mud pit of poverty.

For example, a person's level of education has a significant impact on her future income (Sandoval, 2012). Unfortunately, poor students are likely to spend less time in school than their middle- and upper class counterparts (Schwartzman, 2005). In an attempt to address the short-fall in education for the poor, Bolsa Família requires that children of beneficiary families attend school at least $85 \%$ of the time. So if children miss school too often, or if adolescent children drop out of school, the family no longer receives benefits for that child. This means that parents are given a significant incentive to ensure that children are attending, as well as an effective means of monitoring their children's attendance. Unsurprisingly, much evidence shows that enrollment has increased as a result (Glewwe \& Kassouf, 2012). Unfortunately, it is not clear that the increase in enrollment has had any real impact on educational achievement according to test scores. Some studies find that it has a significant effect on graduation (Baird, McIntosh \& Özler, 2011), while others do not (Baird, Ferreira \& Özler, 2013). This may be a result of the program design, which requires enrollment and attendance, but, unlike programs in several other countries, Bolsa Família does not require grade promotion or graduation.

On the other hand, the enrollment requirement may change the culture surrounding education in Brazil. Since children are spending more time in 
school than they did in the past, and they know that there are financial rewards for doing so, they be more likely to dedicate themselves to academic success. School attendance is a necessary, though not a sufficient condition for grade promotion. Without Bolsa Família, a certain cohort of children would drop out of school. However, the cash transfer, which is conditional on their attendance, provides a large enough incentive to keep them in school. Since the cash incentive persists until they are 18 years old, younger children know that they are likely to remain in school at least until they turn 18. The benefit of an education resembles a step-wise function rather than a curve. An average person's income is unlikely to be affected much by an additional year of schooling, unless that additional year results in graduation. In that case, the individual's likely income will jump significantly. Therefore, enrollment is a necessary condition, but graduation is a sufficient condition for gaining the financial return that education provides.

Imagine a scenario with two children, one who is a Bolsa Família recipient, and an identical child who is not. For the recipient child, call her A, she knows that, because of the conditionality of the cash transfer, she is likely to remain in school at least until she turns 18 . It would not make financial sense for her to drop out. Child B, on the other hand, the child who is not a recipient of the Bolsa Família program, has no additional incentive to remain in school. Since child B knows that there is some chance that he will drop out of school before he has time to reach graduation, he is less motivated to achieve academic success, because the financial payoff from academic success is only unlocked upon graduation. Therefore, the probability of dropping out discounts the expected financial reward from academic success. Child A, however, knowing that she will remain in school until she turns 18 sees that she could be very close to unlocking the financial reward associated with graduation by the time she ages out of the program, if she applies herself to her studies.

In the short term, children whose families enter the program when they are already well into their education may already be far enough behind that they will not be very close to graduation by the time they age out of the program. Therefore, they have no additional incentive to work for academic success. As time passes, however, and children enter their first year of school with the expectation of remaining in school at least until they turn 18 
because financial rewards for doing so are large enough to offset the rewards of dropping out. Consequently, they know that they can be very close to graduation by the time they age out of the program. So the program offsets the rewards of dropping out for long enough that graduation is within reach. The real impact of Bolsa Família on graduation rates may take several years to manifest. It might take 8-10 years before children enter the program at a young enough age to be influenced by the change in their incentives that Bolsa Família creates, and perhaps longer if students and families are slow to adjust to the new incentive structure.

\section{H1: Bolsa Família should improve academic achievement outcomes}

In addition to nutritional requirements for children, the program also offers benefits to pregnant and lactating mothers who are also required to show indications of adequate nutrition. It is expected that as the child beneficiaries are consuming a more nutritious diet due to cash transfers, expectant and lactating mothers, who are also direct beneficiaries of the program, will be doing the same. As a result, after Bolsa's initial impact, proponents expect to see a continued drop in the rate of stillbirths and infant mortality over the long-term with Brazil's Bolsa Família playing a major role in the outcome (Adato, Devereux \& Sabates-Wheeler, 2016; Baird, Chirwa, Mcintosh \& Ozler, 2010). Mexico's Progresa conditional cash transfer program has been attributed to a $17 \%$ decline in rural infant mortality and in some cases neonatal mortality rates (Barham, 2011).

Bolsa Família's nutrition initiatives should also have an effect on mothers. Since an unsuccessful pregnancy may lead to a family choosing to attempt pregnancy multiple times, lower infant mortality and birth rates should reduce the amount of time women are pregnant. More successful births and better infant health will lead to lower birth rates due to fewer pregnancies (Schellekens \& van Poppel, 2012; Scrimshaw, 1978). This will benefit maternal health, and the amount of time and energy mothers are able to dedicate to their surviving children, but it may also lead to more participation in the workforce. Lower infant mortality rates should also lead to better mental health in that it is less likely a family will have to deal with 
the loss of a child. This allots mothers more free time that may, without the program, have been spent strictly on childbearing and health maintenance.

Nutrition is monitored, somewhat crudely, through the required regular medical checkups for pregnant or lactating mothers and children of beneficiary families. Evidence suggests that conditional cash transfer programs are effective in increasing the use of preventative services and, in some cases, improves health status (Lagarde et al., 2007). Long-term health impacts of Bolsa Família due to nutritional supplements and preventative measures should be attributable to increased health and health awareness among the beneficiaries. A healthy child is less likely to be impaired by cognitive or physical setbacks that may result from malnutrition or preventable disease, which will make it easier for her to transition into school and be better equipped to gain an education.

School enrollment and a higher level of grade completion are both goals of the Bolsa program. One of the conditions of Bolsa Família is that all children of beneficiary families between the ages of 6 and 15 must be enrolled in school and attend 85\% of the time (Glewwe \& Kassouf, 2012). Some results from BF indicated that a larger number of children were enrolling in schools. This enrollment however, did not translate into a higher grade level completion rate according to some studies (Baird et al., 2010, 2013). More positive results in this study regarding grade level completion due to the spillover effect of better nutrition and cognitive development as a generation of students who has consistently received adequate nutrition and medical attention progresses through the school system are expected as well. While the original goal was to encourage children to complete 8 years of school, it is anticipated that those who do will also be encouraged to attend secondary school and possibly even pursue a higher education.

Given that teenagers and young adults attend secondary school at higher rates, one might expect this trend to translate into lower birth rates among teenage girls in Brazil. Young girls will have financial incentives to remain in school, which is more difficult for teen mothers (Baird et al., 2013). Moreover, additional education tends to lead to delayed pregnancy (Duflo, Dupas, Kremer \& Sinei, 2006). Results from different CCT's around the world that focus on higher levels of education have all yielded significant declines in the rate of teenage pregnancy for females who are beneficiaries 
of the programs due to sexual education, contraception awareness and dispersal, and family planning education. In Malawi, early marriage, teenage pregnancy and reported sexual activity among teenagers all dropped between 30-40\% due to the Zomba Cash Transfer Program (Baird et al., 2010). An exception is Mexico's Oportunidades where studies show that the number of adolescent and young women reporting ever being pregnant remained flat at 33-36\%, though the use of contraception has been rising steadily (Darney et al., 2013).

\section{H2: Bolsa Família should lead to a reduction in fecundity rates}

With fewer children working and more children completing higher levels of education we should begin to see a direct effect on the job market in Brazil. One study shows that Bolsa initially had a positive effect on the adult labor force with the greatest impact being on women in the work force. It must also be noted that CCTs do not appear to lead people to exit the workforce as some have contended (Soares, Ribas \& Osório, 2010). The logical extension of previous research into this area would suggest that the child beneficiaries of the Bolsa program, once adults, will have a lower rate of unemployment than those in their age range at the beginning of the program. In the long-term, more education should translate into easier attainment of skilled jobs in the formal job market along with the desire of the newly educated young adults to take the skills they have acquired to the job market. There should be a new generation of job-seekers and entrepreneurs who are better positioned to raise their standard of living beyond that of their less educated parents. All else being equal, formal economy work is generally more reliable and offers better pay and benefits than informal work (Banerjee \& Duflo, 2012). The long-term result is that formal economy workers face far fewer of the uncertainties and disruptions that tend to plague informal work, which means more consistent consumption patterns.

H3: Bolsa Família should lead to a reduction in formal economy unemployment 
All three of these factors, child health, education and employment are reliant on one another. Cognitive and physical development will make it easier for a child to perform well in school. School performance should result in greater skills, sense of opportunity, and recognition of an individual's ability to raise their standard of living. This realization that one can raise their standard of living should directly affect participation in the job market.

It is this new generation of skilled laborers that should be the key to eradicating inter-generational poverty. This is due to an influx of human capital as provided by Bolsa that begins with the health of the beneficiaries when they are infants and maintains these benefits through school and far beyond the program's requirements. Proponents expect to see positive changes in most of the societal conditions that Bolsa Família originally intended to combat due to changes in health, education standards, gender roles, and human capital.

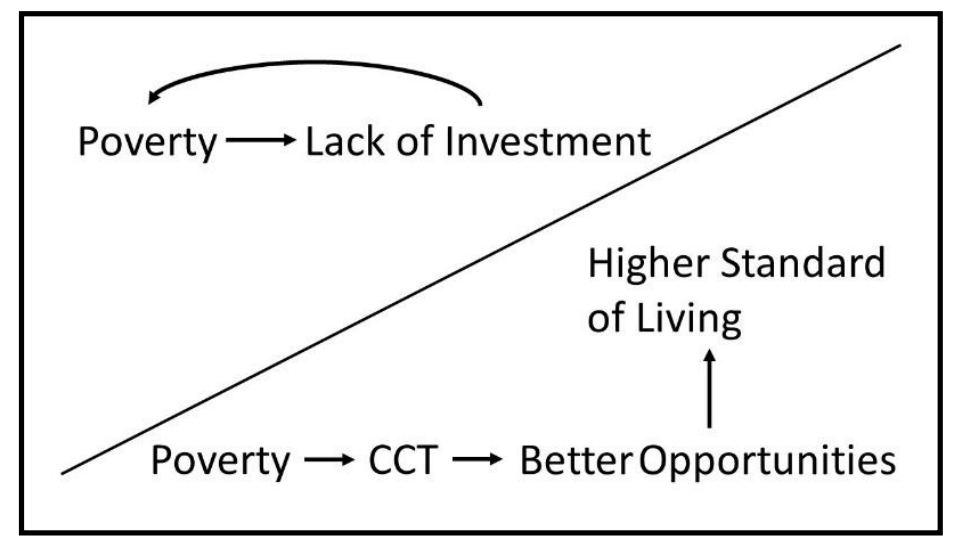

Figure 1. Theoretical Relationships

So, as Figure 1 demonstrates, without CCTs, we often see poverty begetting poverty. Children of poor households are likely to grow up and head poor households of their own. This article is examining whether CCTs can disrupt the intergenerational poverty cycle, as purported by proponents. The next section describes the empirical tests of the hypotheses. 


\section{Empirical Analysis}

The empirical analysis uses data provided by two Brazilian government agencies, the Ministério do Desenvolvimento Social and the Instituto Brasileiro de Geografia e Estatísticas. It tests whether there is evidence of significant change in 8th grade graduation, unemployment figures, child labor and fertility rates during the first decade of the Bolsa Família program. If Bolsa Família is accomplishing its secondary objective, to break intergenerational poverty cycles, we should be able to see more change in key indicators for municipalities that had higher implementation than those municipalities that had low implementation. The key explanatory variable and the dependent variables are endogenous. Therefore, it is necessary to instrument for the key explanatory variable Avg Bolsa Families, or the average number of Bolsa recipient families in each municipality over the years 2003-2010.

Since Bolsa Família, the key explanatory variable, is designed to target the poor, and the dependent variables are all closely related to poverty, there is a problem with endogeneity. Using 2SLS, Bolsa Coverage, or the proportion of people who actually received cash transfers compared to the number the government expected based on official municipal statistics, was one of the instruments. The other instrument was Average Population in the municipality. Statistical tests confirmed that the models were endogenous without instrumenting and that instrumenting solved the endogeneity problem.

The regression analysis shows that Bolsa Família has a significant impact on $8^{\text {th }}$ grade graduation. $8^{\text {th }}$ grade graduation rates were going up all over Brazil, and much of Latin American and the developing world in general during this time period, but municipalities that had more families who were recipients of cash transfers had unexpectedly large gains in $8^{\text {th }}$ grade graduation. Despite school attendance being one of the key conditions for the program, some previous studies have found mixed evidence on actual graduation rates (Bursztyn \& Coffman, 2012; Saavedra \& Garcia, 2013). So a statistically significant result here is meaningful. The substantive impact, shown in Figure 1, is noteworthy too. Increasing Bolsa recipient families by ten per thousand population increases $8^{\text {th }}$ grade graduation by a predicted 
$2 \%$. This result should be encouraging for CCT proponents, considering some previous studies have found no impact at all. On the other hand, Bolsa Família is not going to single-handedly spike educational outcomes across Brazil.

Table 1.

Summary Statistics

\begin{tabular}{llllll} 
Variable & Obs & Mean & Std. Dev. & Min & Max \\
\hline 2000-2010 Change In & & & & & \\
8th grade graduation rate & 53716 & 0.481 & 0.130 & 0.032 & 0.855 \\
Unemployment rate & 60247 & 3.995 & 5.004 & -32.47 & 42.31 \\
Fertility rate & 60489 & 0.016 & 0.013 & -0.049 & 0.151 \\
Avg Family recipients/1000 pop & 38908 & 76.516 & 39.400 & 2.195 & 217.425 \\
GMP (gross municipal product) & 33331 & 0.034 & 0.400 & 0.001 & 38.499 \\
100k births 2000 & 60489 & 0.270 & 1.369 & 0.007 & 74.042 \\
Fertility rate 2000 & 60489 & 0.050 & 0.017 & 0.002 & 0.173 \\
Avg Population & 61127 & 33879.25 & 200512.5 & 819 & $1.11 \mathrm{E}+07$ \\
Urban & 61138 & 1.577 & 1.170 & 0 & 4 \\
Bolsa Coverage & 61055 & 97.652 & 30.206 & 0.22 & 727.59 \\
\hline
\end{tabular}

Many experts and policy makers involved with CCTs would argue that educational achievement is really just a means to an end. The program was not designed to improve educational outcomes, but to alleviate poverty in the short term and to break the inter-generational poverty cycle in the long-term. One concern that some have expressed, however, is that when poor families receive cash transfers they will work less (Foguel \& Barros, 2010). Table 2 shows a very different conclusion. Instead, the more families who receive cash transfers in a municipality, the lower the unemployment rate is. In fact, unemployment displays the greatest sensitivity to the proportion of Bolsa recipient families in a municipality. Adding ten more recipient families per thousand population reduces unemployment by an estimated $1.8 \%$. 
94 Warby - Long-term Societal Impacts of CCT

Table 2.

Long-term Effects of Bolsa Família

\begin{tabular}{llll}
\hline & Graduation & Unemployment & Fertility \\
\hline \multirow{2}{*}{ Recipient families/1000 pop. } & $0.0119^{* * * *}$ & $-0.181^{* * *}$ & $-0.000449^{* * *}$ \\
GMP & $(0.00205)$ & $(0.0440)$ & $(0.000117)$ \\
& 0.0171 & $0.463^{*}$ & -0.000699 \\
Regions & $(0.0104)$ & $(0.233)$ & $(0.000553)$ \\
& $0.176^{* * *}$ & $2.825^{* * *}$ & $-0.00678^{* *}$ \\
Urban & $(0.0389)$ & $(0.843)$ & $(0.00219)$ \\
& $0.0898^{* * *}$ & 0.688 & $-0.00485^{* * *}$ \\
Fertility rate & $(0.0200)$ & $(0.444)$ & $(0.00118)$ \\
& & & $0.684^{* * *}$ \\
Constant & & & $(0.0168)$ \\
& & $-24.60^{* * *}$ & $0.0375^{*}$ \\
$N$ & $\left(0.928^{* * *}\right.$ & $(5.758)$ & $(0.0147)$ \\
\hline
\end{tabular}

Standard errors in parentheses, ${ }^{*} p<0.05,{ }^{* *} p<0.01,{ }^{* * *} p<0.001$; GMP and Coverage are for 2009; Recipient Families is instrumented with Avg Population and Coverage

It should be noted that these are official unemployment figures, and there may be other factors that are hiding part of the relationships. For example, the informal market is robust in much of Brazil and unemployment figures only count people who are actively looking for work in the formal market (Bosch, Goni \& Maloney, 2007). With the figures on greater educational attainment, however, it seems more likely that people are finding jobs in the formal market than in the less efficient, lower paying and riskier informal market. There are other factors that the literature has identified that might have some impact on the relationships in question here, such as electrification, particularly rural electrification (Pereira, Freitas \& da Silva, 2010), the depth of individual poverty (Cardoso \& Verner, 2006), or the structure of industry in an area (Beck, Demirgüç-Kunt \& Levine, 2007; 
Bittencourt, 2010). However, due to data constraints some of those factors cannot be fully accounted for. Because this analysis uses municipal level data, precise indicators for those factors are not available. On the other hand, the control variables included in the models displayed in Table 2 pick up a good deal of that noise, even if in a relatively rudimentary manner. Industry tends to cluster by regions in Brazil, with large scale agriculture concentrated in the central-west and south, or finance concentrated in the south-east. Urban and GMP also help account for some of this statistical noise. The results of more comprehensive regressions are displayed in the appendix. CCTs are, of course, not the only factor that affects poverty. Political institutions (Acemoglu \& Robinson, 2012), trade (Harrison, Rutherford, Tarr \& Gurgel, 2004), economic growth (Ferreira, Leite \& Ravallion, 2010), foreign direct investment (Bonelli, 1999), and a variety of other factors can affect poverty alleviation. However, because this analysis focuses exclusively on Brazil, these variables remain consistent.

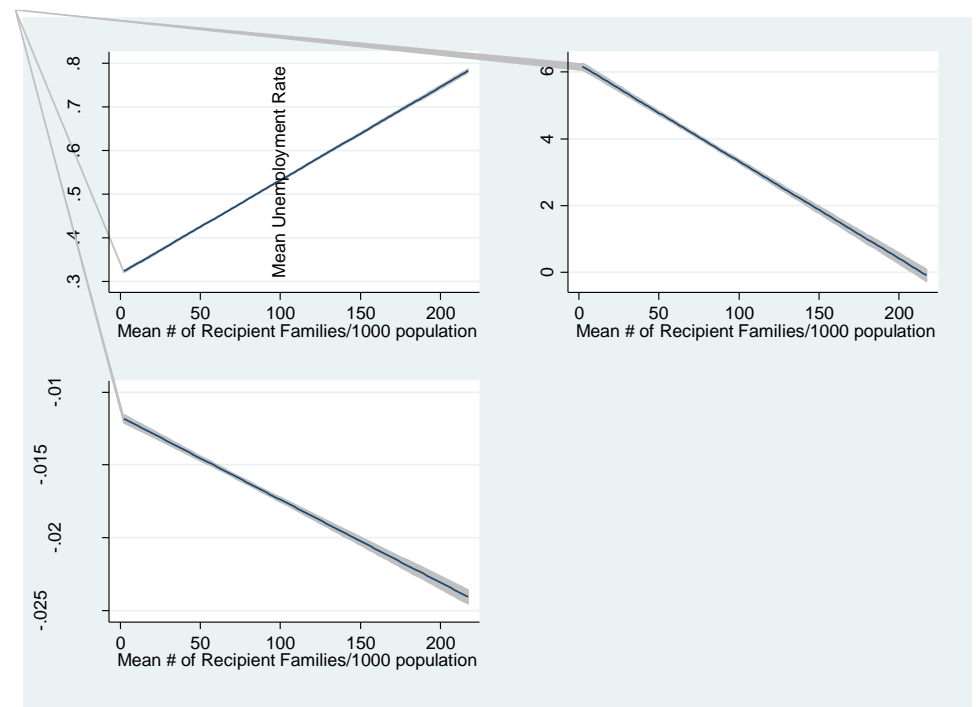

Figure 2. Fitted Line Graphs with 95\% Confidence Intervals

Fertility is used as an instrument for social changes such as female empowerment and family planning. Fertility rates tend to be sticky in the 
short term. The average fertility rate actually grew by .016 nationwide from 2000-2010. Bolsa Família slowed, and even reversed the national trend in increasing fertility rates. Using the same variation in Bolsa Família as before results in a 0.004 decline in poverty. So, adding 40 families per thousand population would reverse the national trend of increasing fertility rates. Nominally, this seems like a small change, but because fertility rates tend to be sticky, this means that we see some of the greatest gains, relative to random variation, from Bolsa Família in fertility rates, second only to unemployment. The gains in fertility rates should be viewed remembering that the program targets women in particular. Women are generally the registered recipients of the cash transfers. This likely gives them more influence in financial decision making in the household and provides them with a freer hand to use the money as they see fit. This female empowerment may be spilling over into young women who are choosing to exercise more control over family planning and implement more conservative family sizes. This may also be directly related to the finding of reduced unemployment. Women may be working more and, therefore, wish to limit their number of children.

As a robustness check, data was coded from Brazil's Instituto Brasileiro de Geografía e Estatística which conducts regular National Household Surveys. This is a useful check because the data is available at the individual level, rather than the municipal level. To determine whether a household is a Bolsa Família recipient, we relied on a coding scheme developed by previous researchers (Foguel \& Barros, 2010). Their method is quite reliable when compared to surveys that included questions about the program. As this is a rather comprehensive survey, it was not difficult to find questions that matched the hypotheses. In order to compare like cases, the following analysis only compares recipient households to non-recipient households that had an income of no more than $\$$ R3000 per month, which approximates the peak income of recipient households. Admittedly, this does not account for family size or cost of living, but it does narrow the analysis to households living in approximately the same sociodemographic space, and, likely, the same neighborhoods. 
Table 3.

PNAD Robustness Check

\begin{tabular}{llll}
\hline & $(1)$ & $(2)$ & $(3)$ \\
& Highest grade & Work permit & Children total \\
\hline Cash Transfer & $0.000518^{* * *}$ & $0.000131^{* * *}$ & $-0.0000549^{* * *}$ \\
& $(0.0000152)$ & $(0.0000191)$ & $(0.00000915)$ \\
Age & $-0.0443^{* * *}$ & $-0.00365^{* * *}$ & $-0.0200^{* * *}$ \\
& $(0.000373)$ & $(0.000323)$ & $(0.000216)$ \\
Sex & $-0.145^{* * *}$ & $-0.103^{* * *}$ & $\cdot$ \\
female $=1$ & $(0.0212)$ & $(0.0137)$ & $\cdot$ \\
Year & $-0.00683^{* * *}$ & $-0.00562^{* * *}$ & $-0.0185^{* * *}$ \\
& $(0.00203)$ & $(0.00169)$ & $(0.00124)$ \\
constant & $18.81^{* * *}$ & $11.95^{* * *}$ & $39.57^{* * *}$ \\
& $(4.070)$ & $(3.385)$ & $(2.487)$ \\
$N$ & 95319 & 10851 & 95111 \\
$R^{2}$ & 0.138 & 0.023 & 0.088 \\
\hline
\end{tabular}

Standard errors in parentheses, ${ }^{*} p<0.05,{ }^{* *} p<0.01,{ }^{* * *} p<0.001$

The results are similar except that the statistical relationships are stronger. In Table 3, the size of the cash transfer has a statistically significant impact on the outcome variable. Results are robust to various model specifications and error term structures. A person living in a household that receives the average stipend of $\mathrm{R} \$ 152$ per month is predicted to progress nearly a full grade level higher than a similar person whose household is not a program recipient. Likewise, an adult is $24 \%$ more likely to have a signed work card, an indication of formal economy employment. Finally, the same person is expected to have fewer children, though the substantive impact here is nearly zero. The model predicts a decrease of less than one child per ten households. Still, the results are robust. 


\section{Conclusion}

The theory predicted that Bolsa Família would yield long-term benefits to recipient families. Indeed, the objective of the program is to go beyond simply addressing short-term poverty alleviation and break intergenerational poverty cycles. If the program is effective, we should be able to see some of these effects manifesting at the societal level as program recipients have been incentivized to seek more healthcare and education. Societal level influences should manifest themselves through higher school completion rates because children are required to attend school in order to receive benefits. Likewise, we should observe lower child labor since children would be spending more time in school and families would have less need of supplementary income after receiving cash transfers. Additional education would help lower unemployment once those recipients entered the labor market because having more education makes them more competitive for formal market employment. Finally, observation should indicated lower birth rates because women will receive more healthcare and health information, and since women have more education they are therefore more likely to secure gainful employment, and the opportunity cost of having more children would be greater.

Using information from the Bolsa Família program on the number of families who received cash transfers in each municipality and comparing against census data, this study finds that Bolsa Família indeed has long-term societal-level impacts. It uses a two-stage least squares regression to analyze the data and find statistically significant relationships for 8th grade graduation, unemployment, child labor and fertility rates. Though the substantive impacts varied, they were all large enough to be meaningful in the national context. It seems likely that these trends will continue into the future and that additional research will verify these findings.

Perhaps the key contribution of this research is to validate conditional cash transfer programs' two-pronged approach to poverty alleviation. Wellrespected research has verified for several years now that CCTs have a significant short-term impact on poverty and now this analysis has found evidence that the programs appear to be breaking down the intergenerational poverty cycle, something that very few social welfare programs 
have accomplished. This also means that the return on investment in CCTs is larger, and perhaps more diverse, than can be detected in the short-term. Bolsa Família appears to be changing the texture of the social fabric by slowly wiping away inter-generational poverty.

\section{References}

Acemoglu, D., \& Robinson, J. (2012). Why Nations Fail: The Origins of Power, Prosperity, and Poverty. New York: Crown Business.

Adato, M., Devereux, S., \& Sabates-Wheeler, R. (2016). Accessing the "Right" Kinds of Material and Symbolic Capital: the Role of Cash Transfers in Reducing Adolescent School Absence and Risky Behaviour in South Africa. Journal of Development Studies, 388(June), 1-15. doi: 10.1080/00220388.2015.1134776

Alderman, H., Hoddinott, J., \& Kinsey, B. (2006). Long term consequences

of early childhood malnutrition. Oxford Economic Papers, 58(3), 450474. doi: 10.1093/oep/gp1008

Baird, S., Chirwa, E., Mcintosh, C., \& Ozler, B. (2010). The short-term impacts of a schooling conditional cash transfer program on the sexual behavior of young women. Health Economics, 19, 55-68. doi: 10.1002/hec.1569

Baird, S., Ferreira, F. H. G., \& Özler, B. (2013). Relative Effectiveness of Conditional and Unconditional Cash Transfers for Schooling Outcomes in Developing Countries: A Systematic Review. Campbell Collaboration.

Baird, S., McIntosh, C., \& Özler, B. (2011). Cash or condition? Evidence from a cash transfer experiment. Quarterly Journal of Economics, 126, 1709-1753. doi: 10.1093/qje/qjr032

Banerjee, A., \& Duflo, E. (2012). Poor Economics: A Radical Rethinking of the Way to Fight Global Poverty. New York: Public Affairs.

Barham, T. (2011). A healthier start: the effect of conditional cash transfers on neonatal and infant mortality in rural Mexico. Journal of Development Economics, 94(1), 74-85. doi:

10.1016/j.jdeveco.2010.01.003

Beck, T., Demirgüç-Kunt, A., \& Levine, R. (2007). Finance, inequality and 
the poor. Journal of Economic Growth, 12(1), 27-49. doi: 10.1007/s10887-007-9010-6

Behrman, J. R. (1996). The Impact on of Health and Nutrition on Education. The World Bank Research Observer, 11(1), 23-37.

Bittencourt, M. (2010). Financial development and inequality: Brazil 19851994. Economic Change and Restructuring, 43(2), 113-130. doi: 10.1007/s10644-009-9080-x

Bonelli, R. (1999). A note on foreign direct investment and industrial competitiveness in Brazil. Oxford Development Studies, 27(3), 305327. doi: 10.1080/13600819908424180

Bosch, M., Goni, E., \& Maloney, W. (2007). The Determinants of Rising Informality in Brazil: Evidence from Gross Worker Flows (Policy Research Working Paper No. WPS 4375).

Bryan, J., Osendarp, S., Hughes, D., Calvaresi, E., Baghurst, K., \& van Klinken, J.-W. (2004). Nutrients for Cognitive Development in Schoolaged Children. Nutrition Reviews, 62(8), 295-306. doi: 10.1111/j.17534887.2004.tb00055.x

Bursztyn, L., \& Coffman, L. C. (2012). The Schooling Decision: Family Preferences, Intergenerational Conflict, and Moral Hazard in the Brazilian Favelas. Journal of Political Economy, 120(3), 359-397. doi: 10.1086/666746

Cardoso, A. R., \& Verner, D. (2006). School Drop-out and Push-out Factors in Brazil: The Role of Early Parenthood, Child Labor, and Poverty.

Cidadania, S. N. de R. de. (2010). Bolsa Família Program.

Collins, D., Morduch, J., Rutherford, S., \& Ruthven, O. (2009). Portfolios of the Poor: How the World's Poor Live on \$2 a Day. Princeton: Princeton University Press.

Darney, B. G., Weaver, M. R., Sosa-Rubi, S. G., Walker, D., Servan-Mori, E., Prager, S., \& Gakidou, E. (2013). The oportunidades conditional cash transfer program: Effects on pregnancy and contraceptive use among young rural women in mexico. International Perspectives on Sexual and Reproductive Health, 39(4), 205-214. doi:

$10.1363 / 3920513$

Duflo, E., Dupas, P., Kremer, M., \& Sinei, S. (2006). Education and HIV/AIDS prevention: evidence from a randomized evaluation in 
Western Kenya. World Bank Policy Research Working Paper, (4024). Ferreira, F. H. G., Leite, P. G., \& Ravallion, M. (2010). Poverty reduction without economic growth? Explaining Brazil's poverty dynamics, 1985-2004. Journal of Development Economics, 93(1), 20-36. doi: 10.1016/j.jdeveco.2009.06.001

Fiszbein, A., \& Schady, N. (2009). Conditional Cash Transfers: Reducing Present and Future Poverty. Washington, D.C.: The World Bank. doi: 10.1001/jama.298.16.1900

Foguel, M. N., \& Barros, R. P. De. (2010). The Effects of Conditional Cash Transfer Programmes on Adult Labour Supply: An Empirical Analysis Using a Time-Series-Cross-Section Sample of Brazilian Municipalities. Estudos Economicos, 40(2), 259-293. doi: 10.1590/S0101-

41612010000200001

Glewwe, P., Jacoby, H. G., \& King, E. M. (2001). Early childhood nutrition and academic achievement: A longitudinal analysis. Journal of Public Economics, 81(3), 345-368. doi: 10.1016/S0047-2727(00)00118-3 Glewwe, P., \& Kassouf, A. L. (2012). The impact of the Bolsa Escola/Familia conditional cash transfer program on enrollment, dropout rates and grade promotion in Brazil. Journal of Development Economics, 97(2), 505-517. doi: 10.1016/j.jdeveco.2011.05.008 Harrison, G. W., Rutherford, T. F., Tarr, D. G., \& Gurgel, A. (2004). Trade Policy and Poverty Reduction in Brazil. The World Bank Economic Review, 18(3), 289-317. doi: 10.1093/wber/lhhO43

Lagarde, M., Haines, A., \& Palmer, N. (2007). Conditional cash transfers for improving uptake of health interventions in low- and middle-income countries: a systematic review. Jama, 298(16), 1900-10. doi:

10.1001/jama.298.16.1900

McCrary, J., \& Royer, H. (2011). The Effect of Female Education on Fertility and Infant Health: Evidence from School Entry Policies Using Exact Date of Birth. American Economic Review, 101(1), 158-195. doi: 10.1257/aer.101.1.158

Pereira, M. G., Freitas, M. A. V., \& da Silva, N. F. (2010). Rural electrification and energy poverty: Empirical evidences from Brazil. Renewable and Sustainable Energy Reviews, 14(4), 1229-1240. doi: 10.1016/j.rser.2009.12.013 
Rasella, D., Aquino, R., Santos, C. A. T., Paes-Sousa, R., \& Barreto, M. L. (2013). Effect of a conditional cash transfer programme on childhood mortality: a nationwide analysis of Brazilian municipalities. Lancet, 382(9886), 57-64. doi: 10.1016/S0140-6736(13)60715-1

Rawlings, L. B., \& Rubio, G. (2005). Evaluating the Impact of Conditional

Cash Transfer Programs. The World Bank Research Observer, 20(1), 29-55. doi: 10.1093/wbro/lki001

Saavedra, J. E., \& Garcia, S. (2013). Educational Impacts and Cost-

Effectiveness of Conditional Cash Transfer Programs in Developing

Countries: A Meta-analysis (CESR Working Paper Series No. 2013-

7). USCDornsife Center for Economic and Social Research.

Sandoval, L. (2012). The Effect of Education on Brazil's Economic

Development. Global Majority E-Journal, 3(1), 4-19.

Schellekens, J., \& van Poppel, F. (2012). Marital Fertility Decline in the

Netherlands: Child Mortality, Real Wages, and Unemployment, 1860-

1939. Demography, 49(3), 965-988. doi: 10.1007/s13524-012-0112-1

Schultz, T. P. (1997). Chapter 8 Demand for children in low income countries. In M. Rosenzweig \& O. Stark (Eds.), Handbook of Population and Family Economics (Vol. 1, pp. 349-430). Boston:

Elsevier. doi: 10.1016/S1574-003X(97)80025-6

Schwartzman, S. (2005). Education-oriented social programs in Brazil: the impact of Bolsa Escola. Instituto de Estudos Do Trabalho E Sociedade. Scrimshaw, S.C.M. (1978). Infant Mortality and Behavior in the Regulation of Family Size. Population and Development Review, 4(3), 383-403. doi: $10.2307 / 1972856$

Secretaria Nacional de Renda de Cidadania. (2010). Bolsa Família Program. Ministério do Desenvolvimento Social e Combate à Fome.

Sen, A. (1999). Development as freedom. New York: Random House.

Soares, F. V., Ribas, R. P., \& Osório, R. G. (2010). Evaluating the Impact of Brazil's Bolsa Familia: Cash Transfer Programs in Comparative Perspective. Latin American Research Review, 45(2), 173-190. doi: 10.1353/lar.2010.0017

World Bank. (2012). Gender equality in development. World Development Report 2012. Washington, D.C. 
International and Multidisciplinary Journal of Social Sciences, 7(1) 103

Brian Warby is Assitant Professor of Political Science at the College of Social and Behavioral Sciences at the University of Northern Iowa.

Contact Address: 335 Sabin Hall, Cedar Falls, IA 50614-0404, United States. Email: brian.warby@uni.edu 